\title{
Migrant Remittances, Livelihoods and Investment: Evidence from Tsholotsho District in the Matabeleland North Province of Zimbabwe
}

DOI: $10.11567 / \mathrm{met} .32 .1 .2$

UDK: 314.74:339.727](689.1:680)

Izvorni znanstveni rad

Primljeno: 01. 06. 2015.

Prihvaćeno: 04. 04. 2016.

\author{
Divane Nzima
}

Department of Sociology and Anthropology, Faculty of Social Science and Humanities, University of Fort Hare, Alice dnzima@gmail.com

\section{Vusumzi Duma}

Department of Sociology and Anthropology, Faculty of Social Science and Humanities, University of Fort Hare, Alice

vduma@ufh.ac.za

\section{Philani Moyo}

Department of Sociology and Anthropology, Faculty of Social Science and Humanities, University of Fort Hare, Alice

pmoyo@ufh.ac.za

\begin{abstract}
This paper traces the developmental contribution of migrant remittances sent from South Africa to the Tsholotsho district of Matabeleland North province of Zimbabwe. Since the discovery of gold in South Africa, Zimbabweans from this region have been migrating to South Africa to seek employment. In recent times, the culture of migration in Tsholotsho continues to strengthen, as women have also joined this previously male dominated livelihood strategy. Debates on migration and development have often centered on the role of remittances as a key instrument for development in migrant sending countries. Governments and multilateral institutions have also taken up remittances as a policy priority with a keen interest. This study was conducted using a mixed methods approach. A total of 159 participants completed self-administered quantitative questionnaires. In addition, 5 in-depth qualitative interviews with key informants were conducted in Tsholotsho, while 10 in-depth interviews with migrants were conducted in Johannesburg, South Africa. The results of this study show that the majority of migrant remittances are largely used for unproductive consumption. However, there also exists a measure of investment owing to the need to satisfy the surging consumer demands within the local economy. In this paper, results have shown that migrant remittances are a key livelihood factor without which many poor people would be severely vulnerable to poverty and hunger.
\end{abstract}

KEY WORDS: migrant remittances, livelihoods, investment, savings, migration, Zimbabwe 


\section{INTRODUCTION}

Recently, there has been a growing importance of migrant worker remittances in development debates. Migrant remittances are proving to be a significant form of financing and livelihood income for households, especially in developing countries. Prominent migration scholars such as De Hass (2010), suggest that remittances are an effective instrument of income redistribution, poverty reduction as well as economic growth, relative to development aid and other governmental development programs. According to Ratha et al. (2015), officially recorded remittance flows to developing countries were estimated to have reached a total of $\$ 436$ billion in 2014 and this figure is expected to rise by $0.9 \%$ in 2015 to reach an estimated $\$ 440$ billion. Therefore, one can imagine the magnitude of remittances, given billions of dollars worth of informal remittances that are not officially recorded. These figures are too high to be ignored hence the justification of research to ascertain the role played by remittances in development, more specifically in the creation of sustainable livelihoods for the poor.

In addition, the Human Development Report 2013 has revealed that the Global South is growing economically, and nearly half of the remittances sent to the Global South are from migrant workers working in neighboring countries within the Global South. This is contrary to the traditional trend where most of the remittances sent to the South, came from the North. There has been growing remittance transfer, for example between South Africa and Zimbabwe where Karombo (2013) in Business Day reported that the cash transfer service is growing and an estimated 6.7 billion is remitted to Zimbabwe per year. This further gives credibility to the findings of the Human Development Report 2013 regarding South-South remittance transfers.

This research was conducted in the Tsholotsho district in the Matabeleland North Province of Zimbabwe. The purpose of this study was to examine the developmental role of both formal and informal migrant worker remittances. This particular research focused only on remittances sent by migrants from Tsholotsho who work in South Africa. While a lot still needs to be done to ensure the use of remittances in the creation of sustainable livelihood, this study revealed that migrant remittances are central in the creation of livelihoods in Tsholotsho. 


\section{Remittances and Tsholotsho in context}

Remittances can mean a lot of things to different people and their particular localities. Zanamwe and Devillard (2009: 72) define remittances as "...the monetary transfers that a migrant makes to the country of origin or, in other words, the financial flows associated with migration". In the context of Tsholotsho the definition of remittances is broad, remittances can mean in-kind goods such as groceries, building materials and many other goods as well as "...financial flows associated with migration..." as defined by Zanamwe and Devillard (2009: 72). These remittances in their broad sense are a very important economic asset in Tsholotsho. When a household member migrates to South Africa, those who remain behind have high expectations that he or she will send remittances either in the form of money or goods. In many cases, upon arrival in South Africa, the majority of the migrants often secure employment in the informal sector. From their income, some are able to send remittances in the form of groceries, furniture, as well as money, most of which are sent through informal channels (Chimhandamba, 2009).

The socioeconomic development of Tsholotsho District relies heavily on the continued remittance inflows. For a very long time, men and recently women have been migrating to South Africa in order to secure their livelihoods. Remittances that they send are the main source of income or livelihood given the fact that recurrent droughts severely compromise agricultural production. In the absence of a secure and productive agricultural system, Tsholotsho's local economy remains heavily dependent on the remittance inflows. Therefore one can tentatively argue that remittances are the main tool that households in Tsholotsho use to offset socioeconomic risks.

What made this research more significant was the fact that it took into account informal remittances which are often not recorded officially; hence their role in development is often played down. Similar studies carried out in Africa, Latin America, and Asia point out that most of these remittances are spent on unproductive consumption, and that they suppress local economic activity (Maphosa, 2005; Bradford, Turnell and Vicary, 2008; Giuliano and Ruiz-Arranz, 2009; Mohapatra and Ratha, 2011). In the case of Tsholotsho, remittances seem to be a tool used to boost local economic activity. In the case where such economic activity refers to agricultural production, it would appear that in the case of Tsholotsho, ecological factors as well as political factors are the main causes of the suppression of local economic activities. People then migrate as a reaction to the already suppressed local economic activity, and the remittances they send provide a 
shield against the risks associated with suppressed local economic activity. The studies mentioned above ignored the role played by remittances in boosting local productive investment, and how the so called "unproductive consumption" stimulates growth as demand for goods and services surges within the local economy (Adams Jr. and Page, 2005; Adams Jr., 2006). As a result, it is important to note that there are varied views on the use of remittances with regards to consumption and investment. Hence the subject is very much subject to debate.

This particular research focused on both formal and informal remittances transmitted to Tsholotsho. The research assessed their meaningful contribution to socioeconomic development as a form of sustainable livelihood strategy. Therefore, we sought to ascertain the role played by these remittances in bringing development to those who remain at home. In essence, the critical question that this study sought to address was whether remittances constitute a meaningful contribution to development. In addition, the study aimed to find out whether remittances are a reliable livelihood strategy as well as to assess how remittances stimulate entrepreneurship in the local economy of Tsholotsho.

\section{LITERATURE REVIEW}

\section{Remittances as a means of livelihood}

A number of researchers in several countries, including Zimbabwe, have explored the role played by remittances in the construction of livelihoods (Sander, 2003; Ellis, 2003; Maphosa, 2007). These studies made unanimous discoveries that contributions made by migrant remittances to household incomes are crucial because they provide a means of livelihood. In addition, recipient households appeared to have better living standards when compared to non-recipient households (Sander and Maimbo, 2003).

It is important to have an understanding of what a livelihood is and how remittances form a very significant part of a livelihood for recipient communities. A livelihood is often looked at as a way through which people make a living; however, this concept is not that simplistic, there are other important factors involved in the creation of a livelihood. Ellis (2003:3) gives a clear view when he states that "[...] the term livelihood attempts to capture not just what people do in order to make a living, but the resources that provide them with the capability to build a satisfactory living, the risk factors that they must consider in managing their resources, and the institutional and policy context that either helps or hinders them in their pursuit of a vi- 
able or improving living". There are positive links between migration and improved livelihoods, remittances are the key to these links as they are important resources that are used to reduce risk factors leading to reduced vulnerabilities.

Previous research done by Bloch (2006) show that despite working under harsh conditions in South Africa, Zimbabwean migrants still maintained strong ties with their families and still sent remittances to improve their livelihoods in Zimbabwe. Bloch (2006) acknowledges that the capacity and volume of remittances sent is limited. However, she points to the structural barriers as a result of the migrants status quo such as being undocumented, hence being exposed to exploitation. Despite the challenges faced by migrants, they are still able to send remittances that benefit their families as well as their communities of origin. Bloch (2006) adds that remittances sent to Zimbabwe are crucial for people's livelihoods given the high level of unemployment in that country. What is evident in Bloch's (2006) findings is that remittances are playing an important role to cushion the lives of many who face a huge income risk stemming from an unprecedented high rate of unemployment. Receiving remittances ensures that people have a better livelihood, hence their vulnerability is reduced.

Many researchers (Ellis, 2003; Hall, 2007; Maphosa, 2007; Ncube, 2010) support the fact that remittances have a positive effect on the asset base of remaining residents and that they reduce vulnerability by offsetting risks, which in the end results in improved livelihoods. An improved asset base is a very important element of building livelihoods and remittances provide this opportunity as is rightfully noted by the researchers mentioned above. The question of whether remittances are a sustainable means of livelihood is yet to be answered. However, what is clear from the literature is that remittances play a big role in improving the livelihoods of the remaining residents. Savage and Harvey (2007) and Maphosa (2007) argue that remittances form an important part of many people's lives around the world. They also argue that billions of dollars flow directly into household incomes in the form of remittances and they suspect that these remittance flows may even exceed foreign direct investment and foreign aid put together. What therefore sets migrant remittances apart from other means of financing is that they have a direct bearing on people's livelihoods as they flow directly into household.

Previous research on remittances in Zimbabwe has shown that there are high proportions of remittance flows going towards consumption (Bracking and Sachikonye, 2006; Maphosa, 2007). An earlier study done by Sanders 
(2003) had similar findings. However, the researcher pointed out that this observable fact must not be seen as a big problem as it is harmonious with the phenomena that largely, migration and remittances are part of livelihood strategies used by poor people in their bid to reduce poverty (Sanders, 2003). Remittances are expected to improve the standards of living. It is this basic tenet that leads Sanders (2003) to conclude that consumption in its own right can have a clear resultant effect of an improved standard of living. To further support this argument, Ellis (2003) argued that though it is an observable reality that most of the remittances are spent on consumer goods as opposed to investment, this is still positive to some extent as it compensates for food deficit, hence ensuring food security during unfavorable conditions. Be as it may, it still remains a fact that for livelihoods to be sustainable there should be some entrepreneurial development of some sort or other means to ensure that remittances are used in ways that will ensure improved livelihoods in the future.

\section{Remittances and investment}

In the previous section, it has been brought to light that earlier literature reached consensus on that migrant remittances are mostly used for consumption purposes. Though some researchers find no major problem with that, others raise concerns. In this section, literature will be reviewed to trace how remittances are possibly allocated towards investment. According to Kapur (2003), evidence regarding the direct impact of remittances on economic development and growth is narrow. Kapur (2003) further points us to the common comments from researchers and officials in remittance receiving countries mournful about the bulk of remittances that are spent on consumption. In the case of the Philippines, Kapur (2003) observed that families above a certain income threshold are found to use remittances for investment. In contrast, the Kapur (2003) remarks that in the case of poor families, it is almost not surprising that remittances are used to supplement subsistence consumption, and for that reason little is saved and very little invested in projects that could stimulate productive investment.

In the case of Mexico Kapur (2003: 18) revealed that "[...] 20\% (an additional cumulative investment capital of nearly US\$2 billion) of the capital invested in micro-enterprises throughout urban Mexico came from remittances. Within the ten states with the highest rate of migration from Mexico to the United States, almost a third of the capital invested in microenterprises was associated with remittances". As much as $20 \%$ seems like a small amount compared to the rest that is spent on consumption, but at 
least there is something going on with regards to productive investment in urban Mexico. The situation is not the same in the rural Mexico which sends the most migrants to the United States of America. This could be attributed to the weak formal credit markets that have been particularly unfavorable to Mexico's small and medium enterprises (Kapur, 2003).

Research done in Burma shows that recipient households use remittances according to a hierarchy of needs; unfortunately, productive investment is not on top of the hierarchy (Turnell, Vicary and Brandford, 2008). A survey conducted in Burma has shown that remittances are overwhelmingly employed in the cause for simple survival, with little in the way for funds left over for investment and other "productive"' purposes that would maximize their development impact (Turnell, Vicary and Brandford, 2008). According to the survey referred to above, a small proportion of remittances in Burma are used in investments such as buying and developing farm land, establishing businesses and paying for education (Turnell, Vicary and Brandford, 2008). The above findings are synonymous with those drawn from previous research in Ghana and Comoros where below 10\% of remittances were allocated for productive investment which was mainly in human capital, such as education and health (Turnell, Vicary and Brandford, 2008).

Research done in Angola reveals that the lack or limited employment of remittances towards productive investment is also a common phenomenon in that country with a vast number of migrants in South Africa and Portugal (Tinajero, 2009). According to this study, "[...] when remittances are invested in 'productive activities' such as small businesses, this does not necessarily mean that remittances will contribute to generate profit, or create employment" (Tinajero, 2009: 104). The above concerns are said to be particularly true for poorly run businesses, businesses that are in the informal sector, businesses where labour constitute unpaid family members (Tinajero, 2009: 104). The researchers, however, did not reveal why these businesses fail to be efficient or why they are badly run. There is a possibility that most of those businesses may be lacking business management skills.

Studies conducted in Zimbabwe have not been an exception since they also generally point to the fact that most remittances are used for unproductive consumption as opposed to productive investment (Bloch, 2006; Maphosa, 2007; Chimhandamba, 2009; Ncube, 2010). According to Maphosa (2007), remittances that flow to Southern Zimbabwe are mainly used for supporting the families, with a very small proportion being invested in tra- 
ditional businesses such as grinding mills and general dealer stores. In addition, other forms of investment identified by Maphosa (2007) include education, buying livestock as well as farm inputs. According to Ncube (2010), there is a high incidence of entrepreneurial ventures by young men that are influenced by remittances, though this is low in proportion compared to consumption. These ventures include brick molding and restaurants influenced by a high consumer demand. In addition, there are traditional rural businesses such as general dealer stores and bottle stores that are capitalized through remittances (Ncube, 2010). Though the above studies revealed that there is some form of investment taking place though not satisfactory, they are silent on the capabilities and skills of recipient households necessary to utilize remittances for productive investment. In this research paper we make attempts to assess the skills and capabilities present and required for translating the investment opportunities that remittances pose in order to ensure that their effect can be sustainable in the long run, even when remittances stop flowing in.

\section{RESEARCH METHODOLOGY AND DESIGN}

This study followed a mixed methods approach that combines quantitative and qualitative methods. A mixed methods approach allows the researcher to have a holistic understanding of the phenomenon under study (Johnson and Onwuegbuzie, 2004). A renowned philosopher once argued that "[...] A scientist who wishes to maximize the empirical content of the views he holds and who wants to understand them as clearly as he possibly can, must therefore introduce other views; that is, he must adopt a pluralistic methodology [...]" (Feyerabend, 1975: 30). One of such strengths is that numbers can be given more meaning by narratives, while narratives can have more precision owing to the complimentary effect of numbers (Onwuegbuzie and Teddlie 2002). In this study, we wanted to understand the developmental contribution of migrant remittances within the community of Tsholotsho as clearly as we possibly could. The choice to use mixed methods was also influenced by the fact that previous studies on migrant remittances and development carried out in Zimbabwe also used mixed methods (Maphosa, 2007; Mangunha, Bailey and Cliffe, 2009; Ncube and Gomez, 2011). Those studies, just like this one, sought to maximize on the strengths of mixed methods.

The primary unit of analysis in this study was the household. Given the above, the total population of this study consisted of all households in the 
District of Tsholotsho. Though for the purpose of the qualitative part of this study individuals were interviewed, this did not divert any attention from the household as the unit of analysis. The interview respondents, though in certain instances spoke in their individual capacity as influential people in society, they still belonged to a household. According to the Parliament Research Department (2011: 4), Tsholotsho District has an estimated total population of 22191 households. Therefore, this was the total population upon which the quantitative sample of this study was calculated.

The quantitative sample of this study was calculated with the help of Raosoft online sample size calculator. Given the estimated total population of 22191 households, at a margin of error of $5.79 \%$ and a confidence level of $90 \%$, as well as the response distribution of $50 \%$, the ideal sample was set at 200 households. However, we did not manage to achieve a total response rate, as only a total of 159 households agreed to take part in the survey. Despite the aforementioned ordeal, this sample size was still very good as the response rate was approximately $80 \%$ of the total sampled households.

Given the difficulty to acquire a complete list of all households in Tsholotsho, we decided to employ a two stage cluster sampling technique. In the first stage, the population was divided into four geographical clusters. Each cluster was made up of five Wards out of the total twenty Wards. Existing lists of households were then acquired from the Ward Councilors in order to draw up a sampling frame for each cluster. In the second stage, systematic random sampling was employed to select a sample of $\mathrm{N}=50$ from all four clusters. The $50^{\text {th }}$ element was selected from the sampling frame of each cluster. The total of all elements selected from all four clusters at $\mathrm{N}=50$, made up the sample of $\mathrm{N}=200$. However, due to a hostile political environment only 159 respondents agreed to participate. Most of the data was collected towards election and there was a lot of state surveillance in the area. Participants who declined were concerned that the research could expose them to the wrath of authorities. They claimed that they feared the possibility of state agents following up on those perceived to have had contact with external individuals or organizations. In other words, one could say they were not confident that their anonymity was guaranteed. In line with research ethics we respected their choice of not participating.

For the qualitative part of the study, five key informants were selected using a purposive sampling procedure and they participated in the in-depth interviews. In order to qualify to participate in the in-depth interviews, the subjects had to be occupying an influential position in their community. For example, being an influential member of the community could mean that 
one is a senior council official, school teacher, religious leader or senior police official. Local traditional leaders, such the headmen (village head), were given an opportunity to take part in this study; however, they declined the offer. The people selected had to have an in-depth and holistic understanding of the socioeconomic and political landscape of Tsholotsho District.

This study's aim was to find out how migrant remittances sent from South Africa contribute to development in Tsholotsho District in Zimbabwe. As a result, it would not have been complete if there was no attempt to heed the migrant perspectives. Therefore, in addition to the five interviews carried out in Tsholotsho District, a further sample of ten Zimbabwean migrants working in Johannesburg in South Africa were selected purposively. The criteria to qualify as a subject in this qualitative sample were, amongst others, being a member of a household in Tsholotsho District, and having been living and working in South Africa for a period not less than five years. Due to the distinct characteristics of the desired respondents, we had to use both purposive and snowball sampling. Having found the first respondent who possessed all the desired characteristics, we had to rely on referrals in order to find the other respondents with similar characteristics given the difficulty to access migrant communities. Snowball sampling was the only way we were able to reach our participants and gain their trust through their friends; hence, we were able to earn trust by association.

\section{RESEARCH FINDINGS AND DISCUSSIONS}

\section{Livelihoods and remittances in Tsholotsho}

Subsistence agriculture has been the main source of livelihood for many families in Tsholotsho for a long time. However, harsh ecological conditions have severely compromised the livelihood strategy of locals to subsist. According to Ncube (2010), Tsholotsho District is prone to drought; hence, people are forced to grow drought-resistant crops such as millet and sorghum. This is what TRSR 03, who is a religious leader in the community, had to say regarding the livelihood risks faced by Tsholotsho residents:

Tsholotsho like any other rural area, people farm in order to get food. Some keep animals such as goats, sheep and even cattle. The problem is that there is no rain here for instance we have not had good rains in the past ten years. This has led to loss of crops and even animals die because of lack of water, and grass gets finished and animals do not have food. (interview TRSR 03, December 2012) 
As a result of the uncertainty surrounding the main source of livelihood with risks such as crop loss as identified by advocates of The New Economics of Labour Migration (NELM) theoretical model such as Taylor (1999), the people find themselves vulnerable to poverty and hunger. According to De Haas (2010), NELM states that when people find themselves facing eminent risks, there emerges a need within them to self-ensure against such risks. Therefore, this implies that when the means of livelihood is found to be prone to risk, people are likely to search for alternatives in order to diversify their resources.

The alternative means of livelihood will then serve as insurance in the event that the main source of livelihood fails to yield favourable results. There are many strategies that people can employ to earn a living. However, it seems that people in Tsholotsho have embraced migration as a livelihood strategy for a long time owing to poor employment opportunities locally. Migrant remittances have for a long time served as self-insurance against risks associated with drought in Tsholotsho (Ncube, 2010). Since migration is often a household decision to diversify labour, remaining household members are likely to remain carrying on with cultivating land or in some cases secure employment (Massey et al., 1998; Taylor, 1999; De Haas, 2010).

\section{Household ways of earning livelihood income}

In order to determine the extent to which households in Tsholotsho District are dependent on migrant remittances, it is essential that we examine the different ways through which households earn their livelihood incomes. This will also assist in determining the extent to which the remittances received are sufficient to provide an adequate means of livelihood. The following chart shows the percentages of surveyed household principals who are employed, unemployed and those who are self-employed. 
Figure 1. Household principal's employment status

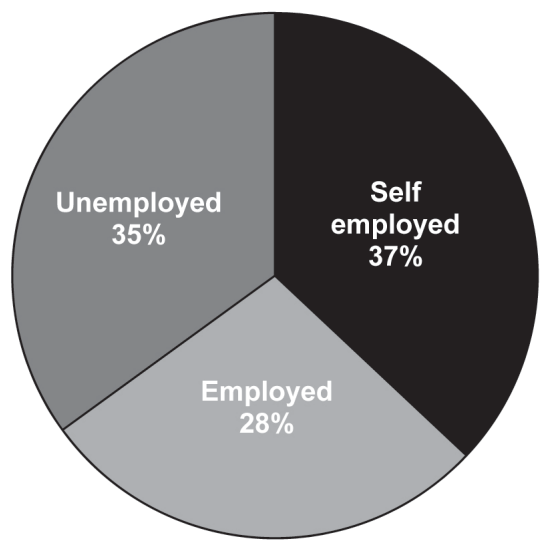

The above chart shows that of the total households surveyed, $37 \%$ of the household principals were reported to be self-employed. Another $35 \%$ of the total survey was reported as unemployed, while only $28 \%$ were found to be employed. The observable low rate of employment in Tsholotsho was attributed to a lack of industry in Tsholotsho which left people with opportunities of employment only in the few government institutions. What is significant to note is that most of the household principals who were employed did not have any household member in South Africa; hence, their livelihood was solely dependent on the income from employment. However, according to one of the interview respondents, Tsholotsho residents were disenfranchised by the lack of education which limited their chances of earning a living through employment, especially in government institutions.

... the people of Tsholotsho find it difficult to secure employment in Tsholotsho $[\ldots]$ government jobs such as in the police force, nursing and teaching amongst others were being taken by people from other areas. (interview TRSR 03, December 2012)

It is also important to note that even TRSR 03 himself was not from Tsholotsho by origin, he just found employment in Tsholotsho. TRSR 03 identified lack of education as the reason for the people of Tsholotsho's failure to secure government jobs. In addition, the respondent said that in Tsholotsho students performed poorly in subjects such as mathematics, sciences 
and English. According to the respondent, mathematics and English are the main requirements for employment within the government. Since the people of Tsholotsho performed poorly in those subjects, that meant that they could not be employed and hence the government jobs went to people from other parts of the country. Consequently, the people of Tsholotsho resorted to migrating to South Africa. Previous studies have cited lack of education as one of the main reasons leading to the failure of rural dwellers to secure employment (Kapur, 2003; Maphosa, 2007; Solidarity Peace Trust, 2009; Tinajero, 2009; Mohapatra, Ratha and Silwal, 2010).

The $37 \%$ that was reported to be self-employed was mainly involved in informal trading while others had small businesses such as general dealer stores, bottle stores, grinding mills and so on. The aforementioned findings regarding the nature of economic activities carried out by the self-employed survey participants are similar to the findings made by Maphosa (2007) and Ncube (2010). The bulk of those who were self-employed were observed to be involved in very small ventures that seemingly did not yield adequate returns such as making crafts, and this in most cases was done part time. Migrant remittances still remained their main means of livelihood. This was well captured by JHB 07 who had been a migrant worker in South Africa for seven years:

My mother makes crafts such as traditional mats and sometimes I send her clothes to sell. Still she does not make much and I still have to send some money home... I think there are few customers that is why she cannot earn a living from what she does so I send money home every month. (interview JHB 07, May 2013)

The above response spells out the fact that despite the reality that people in Tsholotsho derive their livelihoods from other activities such as self-employment and employment, the income they earned remained inadequate for a sustainable livelihood. This finding was also evident from the results of the survey as shown in the following chart. 
Figure 2. Sufficiency of income excluding migrant remittances

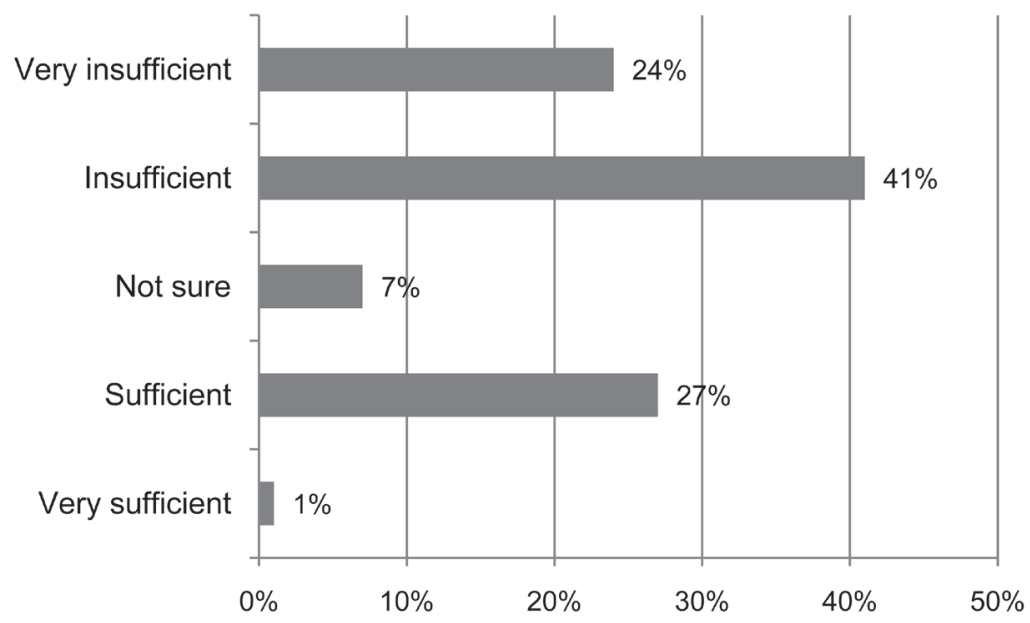

The above figure shows that without migrant remittances most households find themselves faced with income vulnerability. A total of $65 \%$ respondents reported that their income excluding remittances was insufficient, only $28 \%$ reported to have enough income, while $7 \%$ of the total households were not sure if their income was adequate. Be that as it may, the picture that is painted by the survey findings is a dark one. According to Sustainable Livelihoods Approach (SLA), the ability to create sustainable livelihoods is affected by the poor's vulnerability contexts (Ellis, 2000; Cahn, 2006; Maitah, Salem and Abubaker, 2011). In the case of Tsholotsho one can argue that financial assets are a hurdle to the achievement of positive livelihood position. As argued by NELM, poor rural people such as those from Tsholotsho, are prompted to diversify their human capital in order to address their adverse financial position through earning migrant remittances (Taylor, 1999; De Haas, 2010). The above argument was also echoed by one of the interview respondents when he said:

...without the money I send eh mmmh things will be very difficult. You see the money they make is too little it can't sustain them. Even in families where some people are employed things are difficult. Civil servants are given 200 and something dollars what can you do with that per month? At least if I send money they can buy food and farm inputs to produce more food. (interview JHB 10, May 2013) 
Drawing from the sentiments made by the respondent above, one would attest to the fact that remittances are a key financial resource in the creation of livelihoods in Tsholotsho. Moreover, the findings of this study are in sync with arguments made by Taylor (1999) that poor people migrate to ensure that their households acquire remittances which serve as a capital asset used to increase the productivity of other assets that they would already be in possession of such as land. According to Taylor (1999), the NELM theory postulates that remittances are important because poor households often utilize them to buy farm inputs such as fertilizers, improved seeds, and machinery or irrigation equipment. Drawing from the above interview respondent it is evident that remittances are essential in the aforementioned regard as he made reference to their use in acquiring farm inputs to enable growing more food.

It is evident that without migrant remittances, households would find life very difficult as most of the livelihood strategies they employed were often supplemented by income from migrant remittances. In the next section we will present findings on the nature and channels of remitting, amount and different uses of these migrant remittances.

\section{Migrant remittances and investment in Tsholotsho}

Previous studies have raised concerns over the use of migrant remittances on what they termed "unproductive consumption" as opposed to productive investment (Kapur, 2003; Maphosa, 2005; Bradford, Turnell and Vicary, 2008; Guiliano and Ruiz-Arranz, 2009; Ncube, 2010). Preceding studies did not take into account the availability of investment opportunities which is a necessary factor in creating an enabling environment for investment. This section will present findings of this study with regards to the above mentioned as well as the nature of common business ventures in Tsholotsho and factors affecting investment.

\section{Opportunities of investment}

Other studies that were conducted in Matabeleland region revealed that households that invested often did so in traditional businesses such as grinding mills and general dealer stores (Maphosa, 2007; Ncube, 2010). Though one could argue that these studies, tried to identify investment opportunities their attempt was not extensive. This present study attempted to go deeper by searching for investment opportunities that are being utilized and those that could be utilized. The graph below shows the investment opportunities identified by households in Tsholotsho. 
Figure 3. Investment opportunities

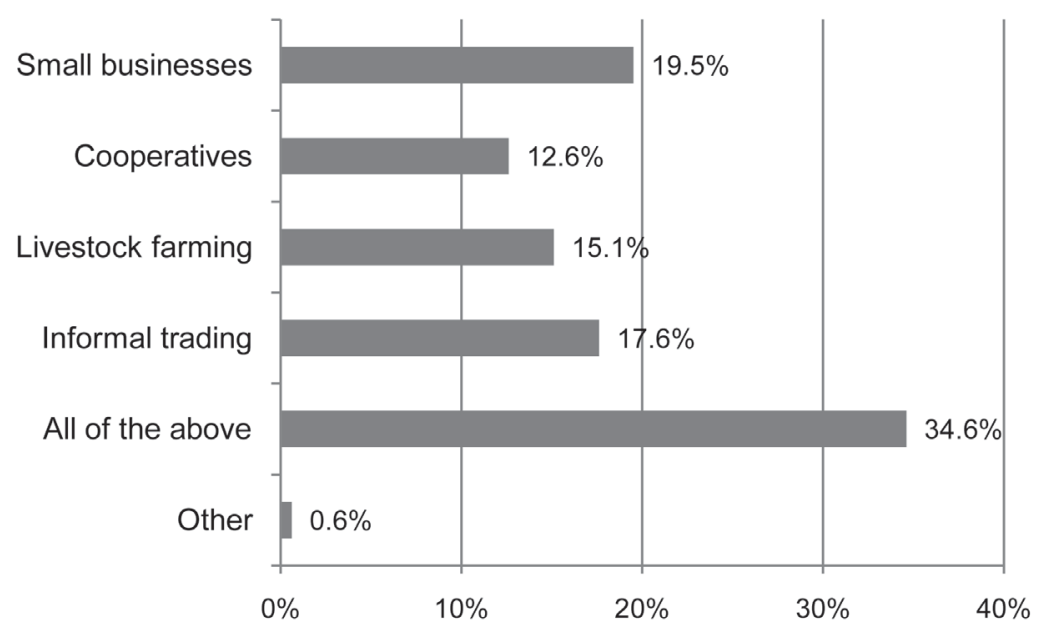

This present study has revealed that investment opportunities are present in the rural district of Tsholotsho. As could be observed from the figure above, survey findings show that $19.5 \%$ of the households identified opportunities of investment in small enterprises. In addition, other investment opportunities that were identified included cooperatives (12.6\%), livestock farming $(15.1 \%)$ and informal trading $(17.6 \%)$. This study has revealed that some recipient households use their remittances to invest in some of the opportunities identified above. However, some claim that their remittances are not sufficient to cover their basic needs and remain with something to invest despite the availability of investment opportunities. In a study conducted by Kapur (2003) in Mexico most of the investments associated with remittances took place in the urban areas and very little investment took place in the rural areas due to the insufficiency of the remittances they received. It would appear that, though there is some investment taking place in the rural district of Tsholotsho, the rate of investment is still low; yet, the people claim to be in possession of skills. Interview respondents also identified more investment opportunities that they believed recipient households could utilize with some support from the government. These include possible investment in timber, tourism, ivory and mining. The following interview responses captured the above claims:

So there are resources, but really the local people are not benefiting from the local resources that are there. We have got minerals, timber, there is wood but 
government has put restrictive measures so that only certain individuals can harvest but there is no meaningful gain that is going towards the people. (interview TRSR 04, December 2012)

As could be deduced from the above interview response, Tsholotsho has resources that could be used to benefit the poor people. With the inflow of remittances people could form co-operatives and invest in timber. However, restrictive measures put in place by government stand in the way of people utilizing this investment opportunity. There is a possibility that government could even "push aside" the poor people and grab the opportunities for itself or rather the ugly culture of corruption could emerge resulting in these opportunities being reserved for the political elite. According to SLA, structures, policies and processes at times become structural barriers that broaden the vulnerability contexts of the poor (Farrington et al., 1999; Ellis, 2003; Cahn, 2006). It appears that in the rural district of Tsholotsho poor people are restricted by repressive government policies to invest some of their remittances in widely available resources such as timber. People in Tsholotsho argued that the process of obtaining a license is too cumbersome and very lengthy, and costs a fortune. Some local people have previously organized themselves into groups and attempted getting licensing to harvest timber to no avail. However, they lament that foreign companies and the political elite seem to be having it easy as they are major players in the industry. Most of the participants feel there is discrimination against locals in the manner in which licenses are issued and they feel big companies get preferences because they are able to pay huge facilitation fees which poor local cannot afford. In addition, people also cited the availability of elephants which could also open a wide window for investment:

...we also have our elephants here and they are the best in the whole of Zimbabwe... People can harvest ivory and sell it. (interview TRSR 02, December 2012)

Tsholotsho district is located at the edge of the Hwange National Park. In this research we found that there are many elephants in the area and they pose a very good investment opportunity. With the cooperation of the government, people can use remittances to invest in tourism as well as legal ivory-trading, given that the residents believed their elephants were the best in the country. Having noted that the above opportunities may require a lot of capital, participants in this research study advocated for the formation of cooperatives so that people can pull their resources together and achieve a great deal of investment. However, participants in this research 
study felt that the most accessible opportunities are in livestock farming because that is something that they are very familiar with:

.... it is important that when people receive money they must not consume all of it, they must have something they are doing. A person can have a small business or (isifuyo) livestock, a person can start with something small like a goat, once one has enough goats she/he can sell them and buy a cow. (interview TRSR 02, December 2012)

Preceding studies have revealed that in the rural areas the most common investment is livestock. People use their remittances to invest in chicken, goats, sheep, donkeys and cattle (Maphosa, 2007; Ncube and Gomez, 2011). It is common belief that for a person to be respected in the rural areas of Matabeleland, he/she must have livestock. Drawing from personal observations and research participants it was observed that the majority of remittance recipient households had more livestock than non-recipient households. The findings of this research study revealed that recipient households took advantage of opportunities of investment in livestock more than any other. Interview respondents of this research study revealed that during holidays when migrants are back, they are usually able to buy two to three cows.

What is observable from this section is that the rural district of Tsholotsho has a number of investment opportunities that recipient households could take advantage of and create sustainable livelihoods for themselves. However, with the low rate of investment of remittance income one would be correct to believe that there are other barriers that restrict people from investing in the widely available opportunities. The next section will present findings on the factors that affect the investment of income from remittances despite the availability of skills and opportunities.

\section{Factors affecting investment}

According to SLA, in order to create working development interventions there is a need to understand the vulnerability contexts of poor people (Chambers and Conway, 1992; Bebbington, 1999; Ellis, 2000; Cahn, 2006). Several migrant remittance studies have arrived at similar findings reiterating the failure of using remittances for productive investment, but rather having a large proportion allocated for unproductive consumption (Kapur, 2003; Bloch, 2006; Bracking and Sachikonye, 2006; Mangunha, Bailey and Cliffe, 2009; Ratha et al., 2011). These preceding studies have often failed to assess the vulnerability contexts of the poor in migrant remittance recipient communities. This present research study revealed that in the case of 
Tsholotsho, skills and investment opportunities were not a problem. However, despite such good preconditions for investment, rates of investment still remained low. This therefore prompted a need to assess other possible factors that could give explanation to the low rate of investment despite the availability of skills and opportunities of investment. The following figure illustrates some of the challenges that affect the ability of recipient households in using their remittances to create sustainable livelihoods through investment.

Figure 4. Factors affecting investment in Tsholotsho

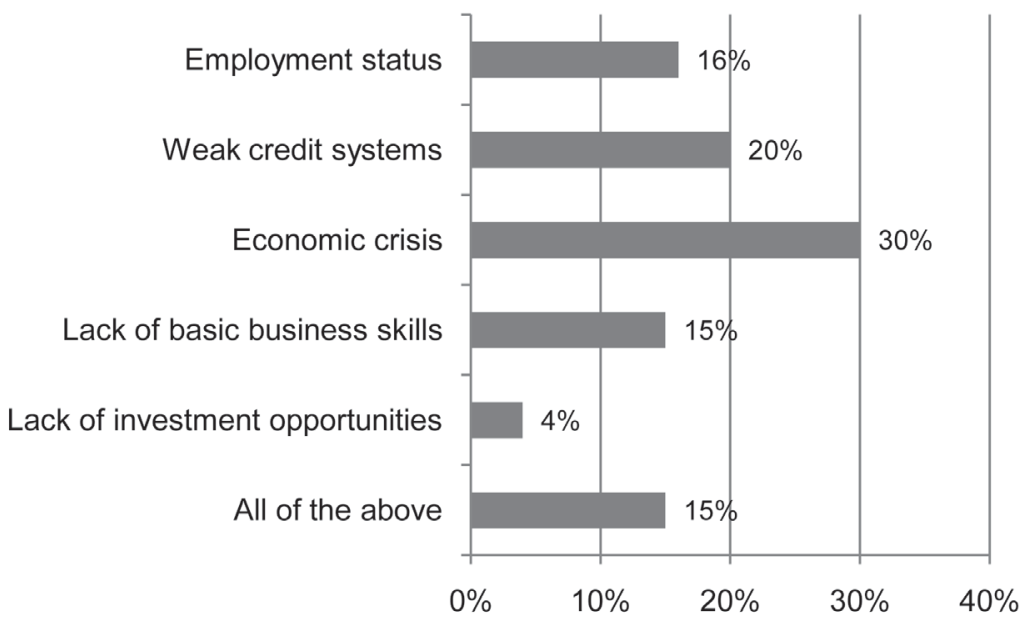

The above figure illustrates that above $60 \%$ of the respondents pointed to factors that are economical in nature as a hindrance to investing remittances while less than $20 \%$ pointed to the lack of skills and opportunities. As could be observed, $30 \%$ of the households in Tsholotsho cited the economic crisis that has affected Zimbabwe for the past decade as one of the major barriers to investment. Previous studies have often referred to the economic crisis in a bid to explain the high rate of migration from Zimbabwe to other countries including South Africa (Ncube, 2010; Ncube and Hougaard, 2010). Given these survey findings of our research, it would appear that while the economic downturn pushed masses away, it also went further to cripple the remaining household members' ability to invest the remittances they received. Another 20\% blamed the failure to invest their remittances on the weak credit systems in the local economy and the country at large. It could also be argued that the lack of an efficient credit system is a resultant effect 
of the economic crises. Interview respondents strongly felt that the lack of financing was the main cause for a high incidence of consumption of remittances as opposed to investment. The following quote is evidence for the above claim:

I think the real problem is not skills but it is lack of funding. If people can get loans they can use these opportunities... Skills are things that people have here. (interview TRSR 05, December 2012)

In the present research study we have come to a finding that the major problem that leads to limited investment in Tsholotsho is lack of funding. As observed in the above quotation, people do have multiple skills and there are various opportunities of investment that they can use. Hence, it would be reasonable to argue that, with a bit of funding, the rate of investment related to migrant remittances could probably increase. Studies have shown that, with the low amounts of remittances received in the communities of origin, most of which are seldom regular, these are often insufficient to cover basic needs. This makes it even more challenging to channel some of these remittances to investment and saving (Savage and Harvey, 2007; Ratha et al., 2011; Orozco, 2012; Chami, 2012). However, one could also argue that with the availability of funding, the remittances could be supplemented and this could lead to possible high rates of investment.

\section{CONCLUDING ARGUMENTS}

\section{The role of migrant remittances in the creation of livelihoods}

The analysis of the results of this research study has shown that migrant remittances are very crucial in the creation of livelihoods in the rural district of Tsholotsho. While we reached a conclusion that the level of remittances received has been low since the introduction of the multi-currency system in the year 2009, remittance-recipient households still have a high purchasing power compared to non-recipient households. The higher purchasing power enjoyed by recipient households influences their high consumer demands. While previous studies have often condemned the high levels of consumption as opposed to investment and savings (Savage and Harvey, 2007; Maphosa, 2007; Chami, 2012), one could argue that the high consumption sets in motion a vibrant local economy wherein entrepreneurs take advantage of the increased demands and set up businesses to meet the demand thereof. In this research study we have come to a conclusion that though some recipient households take part in investment activities, 
it is often the non-recipient households who seize the opportunity of this increased demand emanating from the inflow of remittances into the local economy. In addition, the results of our research revealed that migrant remittance-recipient households do not receive enough income from remittances to allow them to meet their consumption demands, and still remain with extra income to invest or save. This research study revealed that many households in Tsholotsho are large with approximately $60 \%$ having five and above household members, while the majority received remittances averaging between ZAR1000 and ZAR2500. The low levels of remittances makes it very difficult to sustain large households and very little is often left for investment and savings (Tinajero, 2009). According to Ncube (2010), prior to the dollarization of the Zimbabwean economy households could sustain themselves for longer periods with such low amounts of remittances owing to higher foreign currency exchange rates.

The analysis of the results of this research study also show that migrant remittances are the main source of income for recipient households without which many households would find themselves faced with vulnerability. Other forms of earning livelihood income, such as employment, are very limited. The few employment opportunities in the public sector are often taken by outsiders, mainly because the local Tsholotsho people cannot meet the required educational qualifications. Therefore, they put all their hopes of earning a livelihood income into migrant remittances.

In this research study we also found out that, consistent with the theory of NELM, households in Tsholotsho spent some of their migrant remittances on increasing the productivity of livelihoods assets they already possessed, such as land (Taylor, 1999). The income from remittances was used to buy farm inputs such as fertilizers, farming equipments as well as donkeys that are used in cultivating agricultural land. Despite their attempts to increase the productivity of land, which is their main livelihood asset, poor households still fall victim to the adverse ecological conditions such as drought and the resultant crop loss (Ncube and Hougaard, 2010). Others also use their remittances to invest in other forms of earning a livelihood, such as making crafts and engaging in informal trading. However, these activities do not earn them enough livelihood income; hence, they remain dependent on the income from migrant remittances.

In conclusion, migrant remittances are central in the creation of livelihoods in the rural district of Tsholotsho given that above $80 \%$ of surveyed households depended on income from remittances for their livelihoods. However, the low levels of investment and savings still remained the main 
concern. The aforementioned is still a serious barrier towards the creation of sustainable livelihoods. In the event that migrant remittances stop flowing, most of the households are highly likely to face deteriorating standards of living. The results of this research study revealed that $65 \%$ of the households who received remittances prioritized consumption over investment and savings (35\%). However, other scholars such as Sander (2003) argued that migration and remittances form part of the livelihood strategies used by poor people in reducing poverty. The aforementioned is an optimistic assertion that acknowledges that consumption in its own right could have a clear resultant effect of an improved standard of living. To further support this argument from an SLA perspective, Ellis (2003) argued that high proportions of consumption compensates for food deficit, hence ensuring food security during unfavorable conditions. Despite the positive argument for consumption, it still remains true that there is a need to use remittances to create sustainable livelihoods, something that is currently lagging behind in Tsholotsho. Unless there is a high proportion of migrant remittances channeled towards investment and savings, the problem of sustainability of livelihoods remains proliferate in the rural district of Tsholotsho.

\section{Opportunities of investment}

In this study we have come to a conclusion that there are a number of investment opportunities in the rural district of Tsholotsho. The results of this study show that there are investment opportunities in small businesses, cooperatives, informal trading as well as livestock farming in Tsholotsho. Previous studies have shown that households often used their migrant remittances to invest in traditional businesses such as general dealer stores, grinding mills and bottle stores, (Maphosa, 2007; Ncube, 2010). This trend is also noticeable in the rural district of Tsholotsho. This study also revealed that there were other investment opportunities that recipient household could take advantage of. This study revealed that Tsholotsho is rich in timber, elephants as well as minerals. These investment opportunities are currently not being utilized because of repressive government policies. There is a general belief that if government could create favorable policies, people could form cooperatives and pull their resources together, and invest in timber, ivory and even mining. In conclusion, this study revealed that the rural district of Tsholotsho has a number of investment opportunities that recipient households could take advantage of and create sustainable livelihoods for themselves. However, the low rate of investment of remittance 
income leads one to believe that there are other covert barriers that limit households from investing in these extensively available investment opportunities.

\section{REFERENCES}

Adams Jr., R. H. and Page, J. (2005). Do International Migration and Remittances Reduce Poverty in Developing Countries?, World Development, 33 (10): 1645-1669, doi:10.1016/j.worlddev.2005.05.004.

Adams Jr., R. H. (2006). Remittances, Poverty, and Investment in Guatemala, in: Ç. Özden and M. Schiff (eds). International Migration, Remittances and the Brain Drain. Washington, D.C. - Basingstoke: World Bank - Palgrave Macmillan, 53-80.

Bebbington, A. (1999). Capitals and capabilities: a framework for analyzing peasant viability, rural livelihoods and poverty, World Development, 27 (12): 2021-2044.

Bloch, A. (2006). Emigration from Zimbabwe: Migrant perspective, Social Policy and Administration, 40 (1): 67-87, doi: 10.1111/j.1467-9515.2006.00477.x.

Bracking, S. and Sachikonye, L. (2006). Remittances, Poverty Reduction and the Informalisation of Household Wellbeing in Zimbabwe. Global Poverty Research Group, http://www.gprg.org/pubs/workingpapers/pdfs/gprg-wps-045.pdf (5 April 2012).

Bradford, W., Turnell, S. and Vicary, A. (2008). The Remittances of Migrant Workers from Burma: An Economic Analysis of a Survey in Thailand. Naypyidaw: Burma Economic Watch.

Cahn, M. (2006). Sustainable Rural Livelihoods, Micro-Enterprise and Culture in the Pacific Islands: Case Studies from Samoa (Ph.D thesis). Palmerston North: Massey University.

Chambers, R. and Conway, G. R. (1992). Sustainable Rural Lvelihoods: Practical Concepts for the 21st Century. Brighton: Institute for Development Studies (IDS Discussion Paper, 296).

Chami, R. (2012). Workers' remittances and economic development: Realities and possibilities, in: M. Mashayekhi, L. Zhang and D. E. Vivas (eds). Maximizing the Development Impact of Remittances. New York - Geneva: United Nations, 30-38.

Chimhandamba, N. (2009). Reconciling Formal and Informal Benefits of Remittance Channels: A Zimbabwean Migrant's Perspective (Master's thesis). Pretoria: University of Pretoria.

De Haas, H. (2010). Migration and development: A theoretical perspective, International Migration Review, 44 (1): 227-264, doi: 10.1111/j.1747-7379.2009.00804.x.

Ellis, F. (2000). Rural Livelihoods and Diversity in Developing Countries. Oxford: Oxford University Press.

Ellis, F. (2003). A Livelihoods Approach to Migration and Poverty Reduction. Paper commissioned by the Department for International Development (DFID).

Farrington, J., Carney, D., Ashley, C. and Turton, C. (1999). Sustainable Livelihoods in Practice: Early Applications of Concepts in Rural Areas. London: Overseas Development Institute (ODI Natural Resource Perspectives, 42).

Feyerabend, Paul K. (1975). Against Method: Outline of an Anarchistic Theory of Knowledge. London: New Left Books. 
Giuliano, P. and Ruiz-Arranz, M. (2008). Remittances, financial development and growth, Journal of Development Economics, 90 (1): 144-152, doi: 10.1016/j.jdeveco.2008.10.005.

Hall, A. L. (2007). Moving away from poverty: Migrant remittances, livelihoods, and Development, in: D. Narayan and P. Patesdi (eds). Moving out of Poverty. Vol.1: CrossDisciplinary Perspectives on Mobility. New York: World Bank - Palgrave Maemillan.

Johnson, R. B. and Onwuegbuzie, A. J. (2004). Mixed methods research: a research paradigm whose time has come, Educational Researcher, 33 (7): 14-26, doi: 10.3102/0013189X033007014.

Kapur, D. (2003). Remittances: The New Development Mantra? Paper prepared for the G-24 Technical group meeting, September, 15-16, New York and Geneva.

Karombo, T. (2013). Zimbabwe Cash Transfer Service Growing in South Africa. Business Day, April 17, 2013, http://www.bdlive.co.za/business/financial/2013/04/12/zimbabwecash-transfer-service-growing-in-south-africa (18 April 2013).

Maitah, M., Salem, M. and Abubaker, M. (2011). Effective livelihood policies in the assessment of poverty reduction: Protecting the vulnerable, Social and Natural Sciences Journal, 2: 14-17.

Mangunha, F., Bailey, A. and Cliffe, L. (2009). Remittance Strategies of Zimbabweans in Northern England. Leeds: University of Leeds.

Maphosa, F. (2005). The Impact of Remittances from Zimbabweans Working in South Africa on Rural Livelihoods in the Southern Districts of Zimbabwe. Johannesburg: University of the Witwatersrand (Forced Migration Working Paper Series, 14).

Maphosa, F. (2007). Remittances and development: the impact of migration to South Africa on rural livelihoods in the Southern districts of Zimbabwe, Development Southern Africa, 24 (1): 123-136, doi: 10.1080/03768350601165942.

Massey, D. S., Arango, J. Hugo, G., Kouaouci, A., Pallegrino, A. and Taylor, J. E. (1993). Theories of Migrations: A Review and Approval, Population and Development Review, 19 (3): 431-466.

Massey, D. S., Arango, J., Hugo. G., Kouaouci, A., Pallegrino, A. and Taylor, J. E. (1998). World in Motion: Understanding International Migration at the End of the Millennium. Oxford: Clarendon Press.

Mohapatra, S., Ratha, D. and Silwal, A. (2010). Outlook for Remittance Flows 2011-12. Recovery after the Crisis, but Risks Lie Ahead. New York: World Bank (Migration and Development Brief, 13).

Mohapatra, S. and Ratha, D. (2011). Remittance Markets in Africa. Washington, D.C.: World Bank.

Ncube, G. and Gomez, G. M. (2011). Local Economic Development and Remittances in Rural Zimbabwe: Building on Sand or Solid Ground? The Hague: International Institute of Social Studies (ISS Working Paper, 523).

Ncube, G. (2010). Migrant Remittances, Household Livelihood Strategies and Local Development: A Case Study of Village 2 in Ward 19 of Tsholotsho District in Zimbabwe (research paper submitted for a Master of Arts in Development Studies at the International Institute for Social Studies).

Ncube, S. and Hougaard, C. (2010). So Near Yet so Far? Assessing the 90 Day Permit for Zimbabwean Migrants as a Remittances Financial Inclusion Tool. Bellville: University of Stellenbosch, Business school. 
Onwuegbuzie, A. J. and Teddlie, C. (2002). A Framework for analyzing data in Mixed methods research, in: A. Tashakkori and C. Teddlie (eds). Handbook of Mixed Methods in Social and Behavioral Research. New York: Sage Publications, 385-422.

Orozco, M. (2012). Remittances and Assets: Conceptual, empirical and policy considerations and Tools, in: M. Mashayekhi, L. Zhang and D. E. Vivas (eds). Maximizing the Development Impact of Remittances. New York - Geneva: United Nations, 40-49.

Parliament Research Department (2011). Tsholotsho North Constituency Profile. Harare: Parliament of Zimbabwe.

Ratha, D., Mohapatra, S., Ozden, C., Plaza, S., Shaw, W. and Shimeles, A. (2011). Leveraging Migration for Africa: Remittances, Skills and Investments. Washington, D.C.: World Bank.

Ratha, D., De, S., Dervisevic, E., Plaza, S., Schuettler, K., Shaw, W., Wyss, H., Yi, S. and Yousefi, S. R. (2015). Migration and Remittances: Recent Developments and Outlook. New York: World Bank (Migration and Development Brief, 24).

Sander, C. and Maimbo, S. M. (2003). Migrant Labour Remittances in Africa. [New York]: World Bank (Africa Region Working Paper Series, 64).

Sander, C. (2003). Migration Remittances to Developing Countries. A Scoping Study: Overview and Introduction to Issues for Pro-Poor Financial Service. Prepared for the UK Department of International Development (DFID).

Savage, K. and Harvey, P. (2007). Remittances during Crises: Implications for Humanitarian Response. London: Overseas Development Group (Humanitarian Policy Group Briefing Paper, 26), https:/www.odi.org/sites/odi.org.uk/files/odi-assets/ publications-opinion-files/317.pdf (26 November 2012).

Solidarity Peace Trust (2009). Gone to Egoli. Economic Survival Strategies in Matabeleland: A Preliminary Study. Johannesburg: Solidarity Peace Trust.

Taylor, J. E. (1999). The new economics of labour migration and the role of remittances in the migration process, International Migration, 37 (1): 63-88.

Tinajero, S. P. A. (2009). Angola: A study of the Impact of Remittances from Portugal and South Africa. Geneva: International Organisation for Migration.

Turnell, S., Vicary, A. and Brandford, W. (2008). Migration Worker Remittances and Burma: An Economic Analysis of Survey Results. Naypyidaw: Burma Economic Watch.

United Nations Development Programme - UNDP (2013). Human Development Report 2013. The Rise of the South: Human Progress in a Diverse World. New York: UNDP.

Zanamwe, L. and Devillard, A. (2009). Migration in Zimbabwe: A Country Profile 2009. Harare: International Organization for Migration. 


\title{
Migrantske doznake, sredstva za život i ulaganja: dokazi iz okruga Tsholotsho u pokrajini Sjeverni Matabeleland u Zimbabveu
}

\author{
Divane Nzima, Vusumzi Duma, Philani Moyo
}

\begin{abstract}
SAŽETAK
U radu se raspravlja o doprinosu novčanih doznaka koje šalju migranti iz Južne Afrike razvoju okruga Tsholotsho u pokrajini Sjeverni Matabeleland u Zimbabveu. Zimbabveanci iz te regije odlaze u Južnoafričku Republiku u potrazi za poslom još od otkrića zlata u toj zemlji. U novije vrijeme kultura migracija u Tsholotshou i dalje jača, jer su se i žene uključile u tu u prošlosti prevladavajuću mušku strategiju privređivanja. Rasprave o migracijama i razvoju često su fokusirane na ulogu novčanih doznaka kao glavnog instrumenta razvoja u zemlji iz koje dolaze migranti. Vlade i multilateralne institucije također su s velikim entuzijazmom prihvatile doznake kao prioritet politike. Istraživanje je utemeljno na pristupu mješovitih metoda. Ukupno je sudjelovalo 159 ispitanika koji su sami ispunili kvantitativne upitnike. Osim toga provedeno je pet dubinskih kvalitativnih intervjua s ključnim informatorima u Tsholotshou te deset dubinskih intervjua s migrantima u Johannesburgu u Južnoafričkoj Republici. Rezultati istraživanja pokazuju da se većina migrantskih doznaka upotrebljava za neproduktivnu potrošnju, međutim prisutan je i određeni stupanj ulaganja zbog potrebe zadovoljavanja nabujalih potrošačkih zahtjeva u lokalnom gospodarstvu. Također se pokazalo da su migrantske doznake glavni izvor sredstava za život bez kojih bi mnogi siromašni ljudi bili izloženi velikom siromaštvu i gladi.
\end{abstract}

KLJUČNE RIJEČI: migrantske doznake, sredstva za život, ulaganje, ušteđevine, migracija, Zimbabve 